\title{
Kajian Nilai Estetis dan Simbolis Ukiran Masjid Mantingan Jepara
}

\author{
Abdulloh Eizzi Irsyada \\ Desain Komunikasi Visual/STMIK Asia Malang \\ abdulloheizzi@asia.ac.id
}

\begin{abstract}
ABSTRAK
Masjid Mantingan merupakan sebuah masjid tua yang didirikan oleh seorang Adipati Jepara, Sultan Hadlirin dan istrinya Ratu Kalinyamat pada tahun 1481 Saka atau 1559 Masehi. Selain memiliki keindahan dalam arsitektur bangunannya, juga memiliki ornamen-ornamen kuno bermotif bunga, tumbuh-tumbuhan, binatang dan lain sebagainya yang terukir indah di sekitaran dinding-dindingnya. Keaneka ragaman motif, bentuk maupun pola setiap ukiran ini menjadikan peneliti tertarik untuk mengetahui apa saja nilai-nilai estetis dan simbolis yang terkandung dalam setiap ornamen ukiran pada dinding masjid Mantingan Jepara. Nilai-nilai estetis terrepresentasi dalam sebuah media ukir yang kemudian dirancang hingga diukir penuh akan ornamen ukir uang indah, rumit, ngremit dan ngrawit sebagai indikator maju dan tingginya keahlian dan keterampilan seniman ukir Jepara pada masa tersebut. Sedangkan nilai simbolisnya yang penuh akan falsafah kehidupan terrepresentasi atas bentuk komunikasi antar pemimpin (ratu) Jepara pada masa tersebut kepada warganya.
\end{abstract}

Kata Kunci: nilai estetis, simbolis, ukiran, masjid mantingan

\begin{abstract}
The Mantingan Mosque is an old mosque founded by a Duke of Jepara, Sultan Hadlirin and his wife Ratu Kalinyamat in 1481 Saka or 1559 AD. Besides having beauty in the architecture of the building, it also has ancient ornaments patterned with flowers, plants, animals and others that are beautifully carved around its walls. The diversity of motifs, shapes and patterns of each carving makes researchers interested in knowing what are the aesthetic and symbolic values contained in each carving ornament on the walls of the Mantingan Jepara mosque. Aesthetic values are represented in a carving media which is then designed to be fully carved into beautiful, intricate, "ngremit" (sophisticated) and "ngrawit" ornaments as indicators of progress and the high expertise and skills of Jepara carving artists at that time. While its symbolic value is full of the philosophy of life represented by the form of communication between the leader (Queen) of Jepara at that time to its citizens.
\end{abstract}

Keywords: aesthetic value, symbolic, carved, mantingan mosque

\section{PENDAHULUAN}

Jepara sebagai pemilik julukan kota ukir tidak terlepas dari banyaknya aktifitas mengukir dari jaman era Ratu Sima dulu kala, hingga masih dipertahankan hingga masa modern ini. Jejak karya yang dihasilkan seniman ukir Jepara zaman dahulu bisa ditemui di masjid Mantingan Jepara. Masjid Mantingan merupakan sebuah masjid tua yang didirikan oleh seorang Adipati Jepara, Sultan Hadlirin dan istrinya Ratu Kalinyamat pada tahun 1481 Saka atau 1559 Masehi, (Irsyada, 2018, p. 56). Masjid Mantingan terletak di dalam komplek masjid dan makam Mantingan, kecamatan Tahunan, Kabupaten Jepara. Beberapa seni ukir relief berbahankan batu karang putih ini menempel pada setiap dinding dan mimbar masjid Mantingan.

Berdasarkan penelitian-penelitian maupun kajian-kajian yang telah dilakukan, memberikan hasil bahwasannya masing-masing ukiran yang tertempel pada dinding masjid 
Mantingan memiliki nilai estetis dan simbolis. Sebagai contoh, ukiran dengan motif sulursuluran floral yang meliuk-liuk dengan teratur, baik yang simetris maupun tidak, memiliki makna sebagai simbol kesuburan, kehidupan yang dinamis. Suluran dalam kosmologi Hindu-Budha juga merupakan lambang kehidupan dan simbol keseimbangan, serta mengandung makna bahwa untuk memasuki dunia atas harus melalui atau memiliki kesucian dan kesempurnaan, (Na'am, 2006, p. 165).

Kompleks masjid Mantingan selain memiliki keindahan dalam arsitektur bangunannya, juga memiliki ornamen-ornamen kuno yang indah di sekitaran dindingdindingnya. Na'am (2006) dalam Irsyada (2018, p. 57) menyatakan bahwa pada dinding bangunan Masjid terdapat ornamen ukiran Jepara kuno yang bermotif bunga, tumbuhtumbuhan, binatang dan lain sebagainya. Keaneka ragaman motif, bentuk maupun pola setiap ukiran ini menjadikan peneliti tertarik untuk mengetahui apa saja nilai-nilai estetis dan simbolis yang terkandung dalam setiap ornamen ukiran pada dinding masjid Mantingan Jepara.

Latar belakang yang disebutkan sebalumnya menjadikan beberapa rumusan masalah yang akan dijawab pada penelitian ini, meliputi; apa saja nilai-nilai estetis dan simbolis yang terdapat pada setiap ornamen ukiran pada dinding masjid Mantingan? Dan bagaimana nilainilai tersebut mampu terrepresentasikan pada ukiran dinding masjid Mantingan? Adapun tujuan dari dilakukannya penelitian ini adalah untuk mengungkap seperti apa dan bagaimana nilai-nilai estetis dan simbolis pada ukiran masjid Mantingan berdasarkan karakteristiknya yang meliputi motif, pola, bentuk maupun yang lain sebagainya.

\section{PEMBAHASAN}

\section{a) Metode}

Penelitian ini merupakan penelitian kualitatif dengan metode deskriptif. Kualitatif merupakan metode analisis yang berlandaskan pada filsafat post positivisme, digunakan untuk meneliti pada kondisi objek yang alamiah, di mana peneliti adalah sebagi instrumen kunci. Hasil penelitian kualitatif lebih menekankan makna daripada generalisasi, (Sugiyono, 2008 dalam Irsyada 2018, p. 84). Metode deskriptif digunakan untuk menggambarkan atau menganalisis suatu hasil penelitian tetapi tidak digunakan untuk membuat kesimpulan yang lebih luas, (Sugiyono, 2005 dalam Irsyada 2018, p. 84).

Penelitian ini juga menggunakan pendekatan estetis dan historis, karena setiap ornamen yang diukir dan ditempel pada dinding masjid Mantingan memiliki latar belakang perpaduan sejarah, budaya dan filosofis. Pendekatan estetis digunakan dalam menyangkut pembahasan tentang keindahan bentuk dan visual pada setiap ornamen ukir, sedangkan pendekatan historis digunakan untuk memperoleh data sejarah yang melingkupi asal usul objek penelitian berikut nilai simbolis yang terkandung di dalamnya.

Selanjutnya, dalam mengumpulkan data, penelitian ini menggunakan beberapa pendekatan, diantaranya yaitu observasi, studi pustaka serta wawancara. Metode observasi adalah metode yang digunakan untuk mengamati sesuatu, seseorang, suatu lingkungan, atau situasi secara tajam terinci, kemudian dilakukan pencatatan secara akurat dalam berbagai cara. Pada penelitian seni, metode observasi diperlukan untuk mendapatkan data tentang karya seni, mengungkapkan gambaran sistematis mengenai peristiwa kesenian, tingkah laku, dan berbagai perangkatnya (medium dan teknik) pada tempat penelitian (studio, galeri, ruang pamer, komunitas, dsb.) yang dipilih untuk diteliti, (Rohidi, 2011, p. 182).

Menurut R.K. Yin (1987) dalam Irsyada (2018, p. 91), analisis dokumen bukan sekedar mencatat isi penting yang tersurat dalam dokumen atau arsip, tetapi juga maknanya yang tersirat. Adapun buku-buku yang dijadikan bahan studi pustaka di antaranya adalah; 
Seni Kerajinan Mebel Ukir Jepara, SP. Gustami, Kanisius, 2000; Risalah dan Kumpulan Data Tentang Perkembangan Seni Ukir Jepara, Pemerintah Kabupaten Daerah Tingkat II Jepara, Silas Press Jepara, 1979; dan lain sebagainya.

Wawancara merupakan metode lain guna memperoleh informasi tentang kejadian yang tidak dapat diamati sendiri secara langsung oleh peneliti, hal ini dikarenakan tindakan atau peristiwa yang menjadi objek penelitian terjadi di masa lampau ataupun karena peneliti berhalangan hadir di tempat kejadian tersebut, (Rohidi, 2011, p. 208). Wawancara yang dilakukan dengan mengambil informan kunci dan pendukung yang benar-benar memahami dan mengetahui mengenai kajian yang akan dikaji oleh peneliti, diantaranya adalah sebagai berikut: Kiai Nardi, Fakhrihun Na'am dan Afif Isyarobbi, yang merupakan pemerhati sejarah serta Penasihat Umum Komunitas Rumah Kartini Jakarta.

\section{b) Nilai Estetis}

Istilah estetis atau estetika atau "aesthetica" (dalam bahasa Yunani) berarti hal-hal yang dapat diserap dengan pancaindera (The Liang Gie, 1976 dalam Rohmat, 2009, p. 4). Kata aesthestis berarti pencerapan indera (sense of perception). K. Kuypers (dalam Sahman 1993:12) yang dikutip kembali Rohmat (2009, p. 4) menyatakan bahwa pada sekitar tahun 1750, Alexander Baumgarten menggunakan istilah estetika dalam arti cabang filsafat sistematis yang menempatkan keindahan dan seni sebagai objek telaahnya. Dalam perkembangannya, kata estetik diartikan sebagai cabang filsafat dengan maksud membicarakan atau membahas keindahan. Sedangkan Kattsoff (dalam The Liang Gie, 1976) sebagaimana disitir kembali oleh Rohmat (2009, p. 4), menjelaskan konsep estetika sebagai cabang filsafat yang bertalian dengan batasan, rakitan, dan peranan keindahan, khususnya dalam seni. Herbert Read dalam Pengertian Seni (terj. Sudarso 1971) yang dikutip oleh Rohmat (2009, p. 4), menyampaikan definisi keindahan adalah kesatuan dari hubunganhubungan bentuk yang terdapat di antara pencerapan-pencerapan inderawi kita, (beauty is a unity of formal relations our sense perceptions). Sejalan dengan definisi tersebut, keindahan pada dasarnya adalah sejumlah kualitas pokok tertentu yang terdapat pada suatu hal. Kualitas yang paling sering disebut adalah kesatuan (unity), keselarasan (harmony), kesetangkupan (symmetry), keseimbangan (balance), dan perlawanan (contrast), (The Liang Gie, 1976 dalam Rohmat, 2009, p. 4).

Sebagai produk keindahan, karya seni dapat ditelaah melalui perenungan nilai-nilai yang melekat pada karya seni. Tampaknya dalam hal ini muncul suatu problema antara subjek pengamat dengan nilai yang ada dalam karya seni atau nilai yang melekat pada alam pikiran orang yang mengamati karya seni tersebut. Hal ini dikarenakan pembahasan karya seni tidak akan terjadi tanpa melibatkan pengamat sebagai subjek dan karya seni sebagai objek. Dengan demikian kehadiran nilai estetis terletak dalam suatu hubungan di antara sesuatu benda dengan alam pikiran seseorang yang mengamati. Rohmat (2009, p. 5).

\section{c) Nilai Simbolis}

Simbol atau "simbolos" (dalam bahasa Yunani) memiliki arti "ciri, tanda", dalam Kamus Modern Indonesia memiliki arti "lambang", merupakan sebuah hal yang memiliki kandungan arti tertentu dan tersembunyi, layaknya sebuah cincin yang merupakan tanda kesetiaan, atau dalam analogi lain, lampu merah merupakan tanda untuk berhenti dan lain sebagainya, (Zain, 1988 dalam Sunarman, 2010, p. 34). Langer (1976) dalam Sunarman (2010, p. 34-35) membedakan ragam simbol menjadi dua macam, yaitu simbol presentasional, dan simbol diskursif. Simbol presentasional merupakan simbol yang cara penangkapannya tidak membutuhkan intelek, artinya dengan tanpa sadar simbol itu 
menghadirkan apa yang dikandungnya. Simbol macam ini dijumpai dalam alam, dan dalam lukisan, tari-tarian, pahatan dan lain-lain. Simbol diskursif adalah simbol yang cara penangkapannya menggunakan intelek, tidak secara spontan, tetapi berurutan. Simbol ini terungkap secara paling jelas dalam bahasa yang mempunyai konstruksi secara konsekuen. Setiap simbol memiliki suatu nama, sehingga deretan simbol-simbol yang tersusun menurut aturan bahasa tertentu, dapat menghasilkan gambaran mengenai suatu kenyataan tertentu. Simbol seperti ini dibangun oleh unsur-unsur sesuai aturan perhubungan tertentu sehingga dapat pula dipahami maknanya.

Cassirer (1992) dalam Sunarman (2010, p. 35) menambahkan bahwa bentuk-bentuk simbolik itu meliputi seni, mite, bahasa maupun agama. Bentuk lambang atau simbol dapat berupa bahasa (perumpamaan, peribahasa, pantun, cerita ataupun syair), gerak tubuh (tari), suara atau bunyi (musik, lagu), warna dan rupa (hiasan, ukiran, lukisan dan bangunan).

\section{d) Ukiran pada Masjid Mantingan Jepara}

Ukiran dalam bahasa Inggris disebut dengan "carving”, sedangkan mengukir disebut dengan to carve, berpadanan kata lain sculptura yang berakar kata kerja sculptum. Sedangkan pahatan atau ukiran kayu mendapat padanan kata yakni woodcarving, sebagaimana yang diungkapkan oleh Echols-Shadily yang dikutip oleh Sahman (1993) dalam Irsyada (2018, p. 38). Selanjutnya, Syafi'i dan Rohidi (1987) dalam Irsyada (2018, p. 38), mengungkapkan bahwa ukiran kayu merupakan hasil sebuah gambaran yang dikerjakan dengan peralatan pahat kayu, sehingga permukaan yang asal mulanya rata menjadi tidak rata (buledan dan kruwikan).

Ditinjau dari teknik pembuatanya, Chapman (1978) sebagaimana disitir kembali oleh Sahman (1993) dalam Irsyada (2018, p. 38) bahwa "carving is a; it involves cutting away or removing parts of the medium". Pada pekerjaan mengukir, pada dasarnya merupakan proses mengambil bagian-bagian (dari bahan) yang tidak diperlukan sehingga gagasan yang sudah ada sebelumnya bisa dibebaskan dari bongkahan (kayu) tersebut. Jadi dapat disimpulkan bahwa definisi dari ukiran adalah proses mengolah permukaan suatu objek dengan cara mengurangi atau membuang bagian-bagian tertentu yang tidak terpakai pada objek tersebut, sehingga tercipta sebuah objek baru.

Masjid Mantingan merupakan salah satu dari masjid-masjid kuno yang mendapat pengaruh dari beragam budaya. Ia menjadi masjid terbesar kedua yang dibangung setelah masjid Agung Demak pada masanya. Dalam pembangunannya, ditandai dengan sengkalan atau sengkolo (sistem pencatatan tanggal kuno atau chronogram) yang diukir pada dinding mihrabnya. Harjono (2009) dalam Na'am (2006: 64) menyatakan bahwa sengakalan tersebut berbunyi "Rupa Brahmana Warna Sari", yang bilamana diartikan menjadi angka tahun Saka 1748 atau setara dengan tahun 1559 Masehi. Boediman (1982) dalam Mulyani (2013, p. 2) menambahkan bahwa hal yang menarik dari keberadaan masjid Mantingan ini adalah adanya relief hiasan dinding yang memanfaatkan teknik ukir dengan penerapan berbagai ragam hias (ornamen). Ragam hias yang terdapat di dalamnya mendapat pengaruh kebudayaan HinduBudha dan Tionghoa. Hal ini didasarkan pada tampilan visual ragam hiasnya yang banyak memanfaatkan motif bunga lotus atau teratai, labu air, awan, batu karang, dan sulur-suluran (tanaman merambat).

Selain memiliki keindahan pada arsitektur bangunannya, masjid Mantingan juga memiliki keindahan berupa rangkaian ornamen-ornamen kuno yang indah terukir pada sebuah media batu padas kuning yang ditempel pada beberapa sisi dinding masjidnya. Na'am (2006, p. 6) menyatakan bahwa pada beberapa sisi dinding masjid Mantingan terdapt ornamen ukiran Jepara kuno yang bermotif bunga, tumbuhan, hewan dan lain sebagainya. Gustami (2000: p. 8) menambahkan bahwa pada dinding masjid Mantingan terdapat 
ornamen berbentuk binatang yang telah digubah dan tersamar dalam stilasi bentuk kaligrafi Arab, diselingi dengan suluran dedaunan dan bunga, sehingga menjadikan wujudnya sudah tidak memperlihatkan gambaran atau ukiran makhluk hidup lagi. Lombard (1996) dalam Irsyada (2018, p. 58) memberikan contoh pada gambar 1. di bawah, di mana ukiran di atas batu padas kuning tersebut memiliki corak ragam hias Cina, dengan gambar teratai di sekelilingnya dan nampak siluet gambar gajah yang menjadi hasil stilasi suluran dedaunan. Sumber lain, Iswahyudi (2010) dalam Irsyada (2018, p. 58) menyatakan bahwasannya pada setiap ukiran pada batu yang ditempel pada dinding Masjid Mantingan memiliki dua panil relief yang dipahat dengan adegan cerita yang berbeda dan saling membelakangi. Sisi panil yang pertama berceritakan adegan kisah Ramayana yang menggambarkan tokoh Rama, Laksmana serta Punakawan, sedangkan pada panil kedua yang berada dibaliknya menggambarkan sebuah hamparan kolam lotus atau teratai yang daun dan bunganya disusun terstruktur sedemikian rupa sehingga menjadi stilasi bentuk atau gambar hewan gajah.

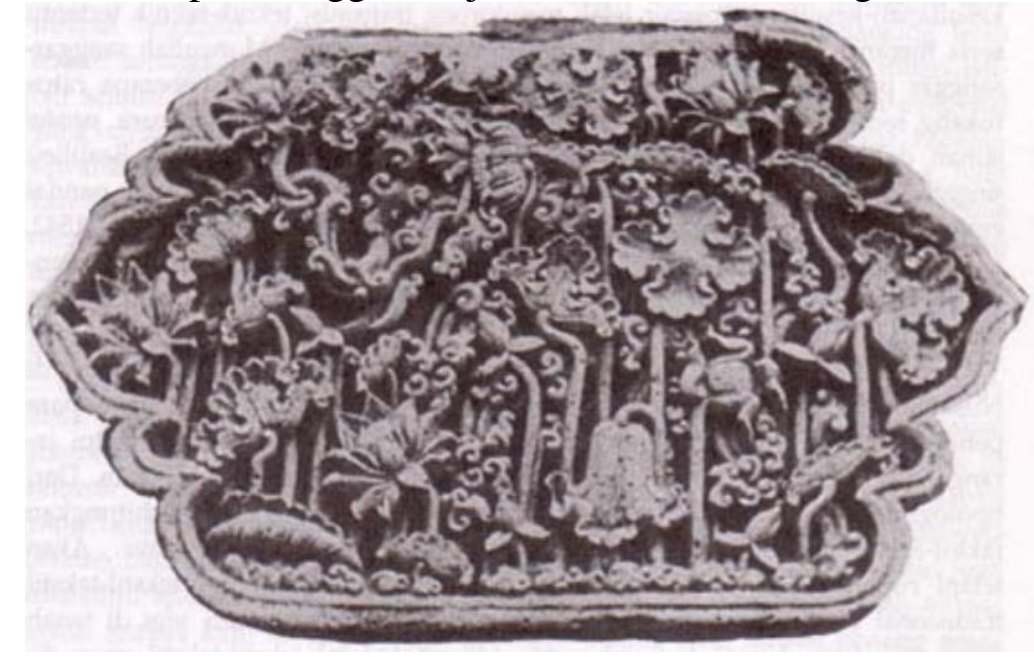

Gambar 1. Potret salah satu ornamen dinding Masjid Mantingan berupa motif hewan gajah yang terstilasi dalam suluran tanaman.

Sumber: Lombard (1996) dalam Irsyada (2018, p. 59).

Dalam sebuah karya seni, nilai estetis yang terkandung di dalamnya bisa bersifat instrinsik ataupun ekstrinsik. Nilai estetis intrinsik merupakan sebuah nilai dari bentuk karya seni yang telah terorganisasi atas unsur-unsur visual dengan menggunakan pertimbangan prinsip desain. Ia lebih mengutamakan pada bagaimana penyusunan struktur bentuk. Sedangkan nilai ekstrinsik lebih menekankan pada makna karya seni, yang selalu melekat pada struktur bentuk karya seni, (Sumardjo, 2000 dalam Rohmat, 2009, p. 5). Sebagai karya seni yang bersifat intrinsik, ukiran pada dinding Masjid Mantingan juga terorganisasi atas unsur-unsur visual yang mencakup bentuk, garis, warna, tekstur serta ruang. Adapun beberapa bentuk bidang ukiran pada dinding masjid Mantingan yang masih terlacak hingga saat ini yakni di antaranya adalah medallion, balok, persegi enam, bentuk letter "W" hingga bentuk kurung kurawal. Sedangkan susunan motifnya meliputi motif makhluk hidup baik hewan yang terstilasi seperti merak, phoenix, kuda, gajah dan kera, maupun floral seperti teratai, suluran dedaunan dan buah, selain itu juga terdapat motif geometris arabesk, abstrak dan landscape.

Ukiran pada dinding masjid Mantingan didominasi oleh panil yang memiliki motif floral, ia terbagi atas motif floral yang menjadi motif utama dan motif floral sebagai motif 
pelengkap atau isian dari motif lain. Motif floral umumnya bisa ditemui pada beberapa panil dengan bentuk yang bersulur-sulur, baik berdiri sendiri menjadi sebuah motif, maupun membentuk samaran motif hewan (stilasi). Motif floral yang terdapat pada ornamen ukir pada masjid Mantingan didominasi oleh motif teratai, baik yang berdiri sendiri sebagaimana ketiga panil di bawah ini, atau sebagai motif pelengkap atau isian, selain itu juga terdapat motif suluran dedaunan dan buah-buahan. Adanya motif floral dedaunan dan buah-buahan yang bersulur-sulur ini merupakan salah satu ciri khas ukiran dengan motif Jepara. Pada masa sekarang motif seperti ini seringkali ditemui pada ukiran ornamen pada gebyok, aneka hiasan dinding, furnitur rumahan dan lain sebagainya yang umum dikerjakan atau diukir oleh seniman ukir Jepara.

Karakteristik tumbuhan teratai adalah bahwa terkadang ia membutuhkan media yang berlumpur dan berlumut untuk tumbuh kembang, berhabitat di dalam area yang keruh atau kurang baik namun mampu hidup dengan keindahan bunga yang dihasilkannya, serta mampu menjadi penopang hidup bagi binatang-binatang yang lebih kecil darinya seperti katak. Ia seolah-olah memberikan pesan kepada manusia untuk mampu trimo ing pandum atau mensyukuri segala apa yang diberikan-Nya baik yang baik dan belum baik, bahkan memiliki kemampuan untuk menghasilkan suatu hal yang bermanfaat bagi siapapun pada kondisi yang sangat buruk sekalipun. Dalam budaya China atau ajaran agama Budha, teratai atau padma atau lotus berkaitan erat dengan simbol kesucian, kedamaian serta kesuburan. Selain itu, bunga teratai yang tengah mekar juga menjadi simbol atas kebenaran dalam berfikir, menimbang, berbicara, serta berbuat atau bertindak.

Sutrisno (2012) sebagaimana dikutip Irsyada (2018, p. 143) menyatakan bahwa adanya motif floral maupun hewan pada suatu ornamen ukir memberikan makna simbol berupa filosofi yang mengakar dalam hidup kerakyatan. Filosofi tersebut memiliki tujuan sebagai simbol atas kesuburan serta kemakmuran. Filosofi semacam ini juga yang sering ditemui pada ornamen dengan motif flora fauna di sekitaran candi-candi di tanah Jawa, seperti Prambanan, Borobudur dan lain sebagainya.
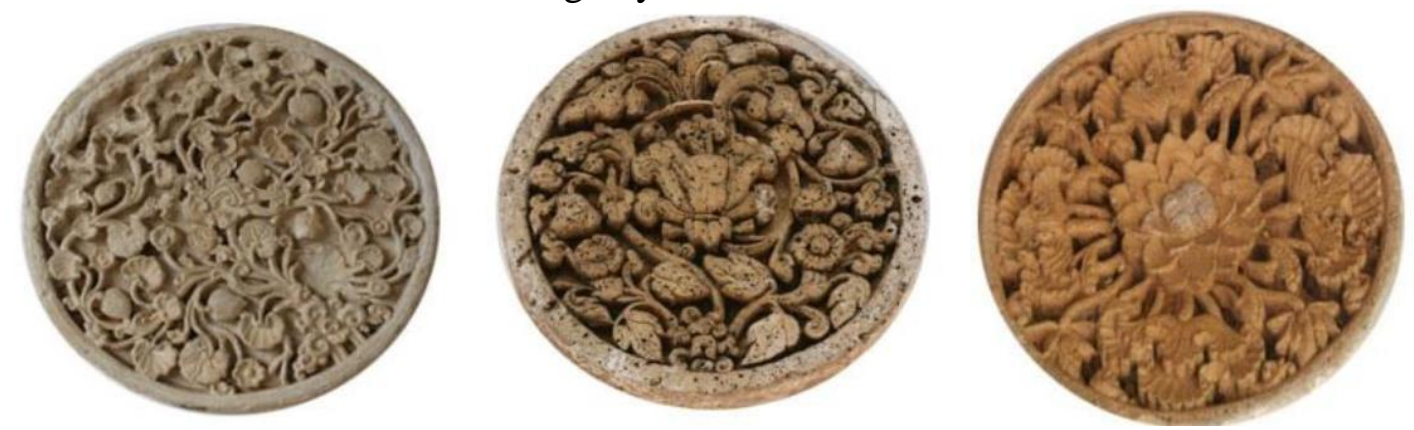

Gambar 2. Ukiran motif floral dengan bentuk bidang medallion.

Sumber: Na'am (2006, p. 87).

Berikutnya, motif hewan pada ukiran dinding masjid Mantingan ini sangat berbeda dengan motif-motif lainnya. Motif hewan diukir dengan cara stilasi, artinya ia tidak terukir secara jelas, namun umumnya diukir samar berdasarkan motif lain seperti suluran floral maupun abstrak lung-lungan yang meliuk-liuk rumit membentuk beberapa hewan seperti merak, phoenix, kuda, gajah, ketam maupun kera. Cara penggambaran hewan dengan stilasi seperti ini merupakan bentuk penghormatan seniman terhadap kepercayaan agama Islam yang melarang adanya penggambaran makhluk hidup, seperti hewan. Sebagaimana Gustami (2000, p. 100-102) nyatakan, bahwasannya hal tersebut (stilasi) merupakan bentuk penerapan unsur estetika Hindu yang diselaraskan dengan ajaran agama Islam, yang dalam 
ajarannya berisi larangan untuk menggambar makhluk hidup. Sehingga, cara gambar stilasi atau tersamar merupakan pemecahan masalah dalam menjembatani keinginan seniman dalam menggambarkan makhluk hidup tanpa harus bertentangan dengan ajaran Islam, di mana ajaran Islam notabene tengah berkembang pesat di tengah masyarakat Mantingan kala itu.

Motif hewan kuda memiliki nilai simbolis yakni menjadi pesan kepada para pengunjung masjid Mantingan bahwa dunia hanyalah sekedar sebagai tempat singgah sementara, karena segala sesuatu akan berakhir dan ditinggalkan. Sehingga, manusia yang merupakan makhluk Tuhan seharusnya selalu mawas diri dan mempersiapkan dirinya kelak untuk mempertanggungjawabkan atas apa yang telah dilakukannya di dunia. Sedangkan motif hewan phoenix memiliki nilai simbolis sebagai pesan kepada manusia sebagai makhluk untuk mampu menjalankan kehendak Tuhan sang penciptanya. Selain itu juga menjadi simbol untuk menghindari menyombongkan diri atas apa yang dimilikinya, karena sejatinya hal tersebut bukan merupak kodratnya menjadi seorang makhluk.

Adapun nilai simbolis dari motif merak adalah menjadi filosofi kehidupan, bahwa kebahagiaan akan mudah diperoleh bilamana seorang makhluk mampu melalui tata laku yang seimbang. Sedangkan kesimbangan hanya dapat dicapai dengan melalui sikap-sikap yang selaras dengan alam, menjaga kelestariannya dan tidak merusaknya. Sedangkan motif kera melambangkan manusia yang telah melalui tahapan laku putih atau pemurnian diri, sehingga mampu mentransformasi sifat-sifat hewaniah dalam diri hingga menjadi seorang manusia seutuhnya, (Na'am, 2006, p. 161).
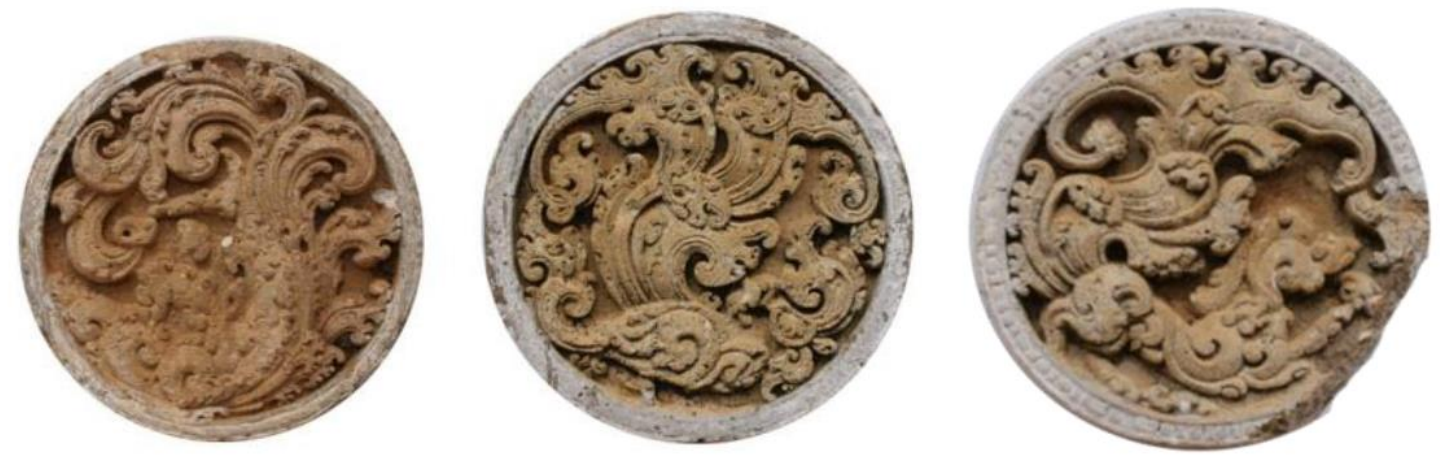

Gambar 3. Ukiran motif hewan (merak, phoenix, kuda) dengan bentuk bidang medallion. Sumber: Na'am (2006, p. 87).

Beberapa panil lain terukir dengan motif arabesk. Secara umum, arabesk atau Arabesque merupakan seni ornamen Islam. Beberapa diantara panil dengan motif geometris arabesk ini juga bisa diidentifikasi motif teratai muncul di tengah atau di pusatnya. Motif teratai ini muncul di tengah-tengah jalinan sulur-suluran geometris yang memenuhi dan mendominasi ruang ornamen dalam bentuk bidang medallion ini. Beberapa panil juga muncul motif dedaunan dan bunga yang menempel pada jalinan suluran geometris sebagai pelengkap atau isian ornamen.

Na'am (2006, p. 158) menyatakan, jalinan suluran geometris yang mendominasi suang ornamen ini seolah menjadi jagad agung (macrocosmos) sedangkan motif teratai di pusatnya merupakan jagad alit (microcosmos). Hal ini mengartikan bahwasannya manusia merupakan jagat kecil dari keseluruhan kehidupan semesta, hendaknya mengerti dan menghayati akan 
posisinya dalam kehidupan (cosmos) ini, dengan Tuhan sebagai Sangkan Paraning Dumadi atau filosofi manusia dalam menyikapi kehidupan.

Irsyada (2018, p. 101) menyatakan bahwa gaya seni ornamen Islam dengan motif geometris merupakan cerminan pertimbangan matematis-rasional, sedangkan hiasan motif geometris dari seni ornamentasi lokal Indonesia muncul atas pengaruh dari citra karya tenun maupun anyaman dalam pandangan simbolik dan imajinatif dari masyarakat agraris.
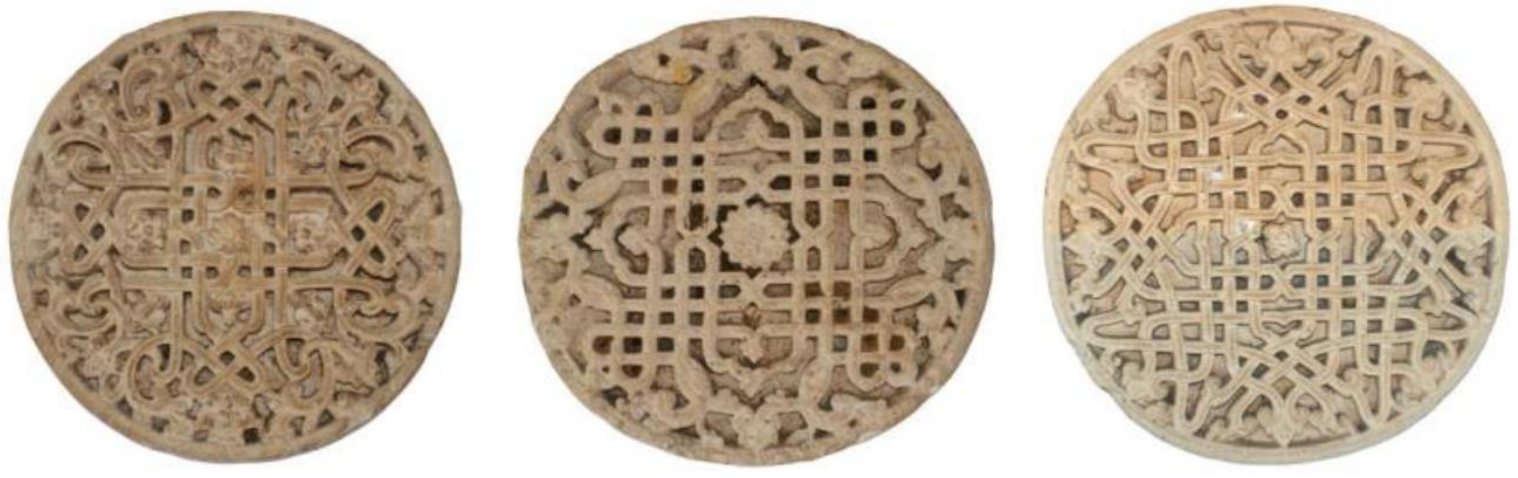

Gambar 4. Ukiran motif arabesk dengan bentuk bidang medallion.

Sumber: Na'am (2006, p. 87).

Panil ukir berikutnya memiliki motif punden berundak dengan susunan geometris dengan bentuk bidang balok. Bila dilihat dari perspektif atas maka panil ini tampak berbentuk persegi. Namun, bila dilihat dari perspektif samping maka akan terlihat bahwasannya panil ini memiliki bentuk berundak dengan bunga teratai yang mengembang serupa matahari berada pada posisi puncaknya. Isian motif teratai yang bersulur memenuhi panil ini, dengan beberapa garis tegas membentuk sudut-sudut persegi yang mengerucut ke atas atau berundak. Dilihat dari strukturnya, panil ini menyerupai punden berundak, struktur area berbatu yang bertingkat atau bersusun atau berundak seperti candi yang digunakan sebagai tempat pemujaan roh nenek moyang pada zaman megalitikum.

Motif punden berundak ini sebagaimana diungkapkan Na'am (2006, p. 161) merupakan simbolis media pengingat kepada manusia untuk faham akan ajaran delapan sifat utama yang perlu dimiliki oleh seorang pemimpin, karena sejatinya setiap manusia diciptakan di muka bumi untuk menjadi seorang pemimpin. Adapun delapan sifat utama seorang pemimpin tersebut adalah, "mahambeg mring warih, samirana, candra, surya, samodra, wukir lan dahana". 


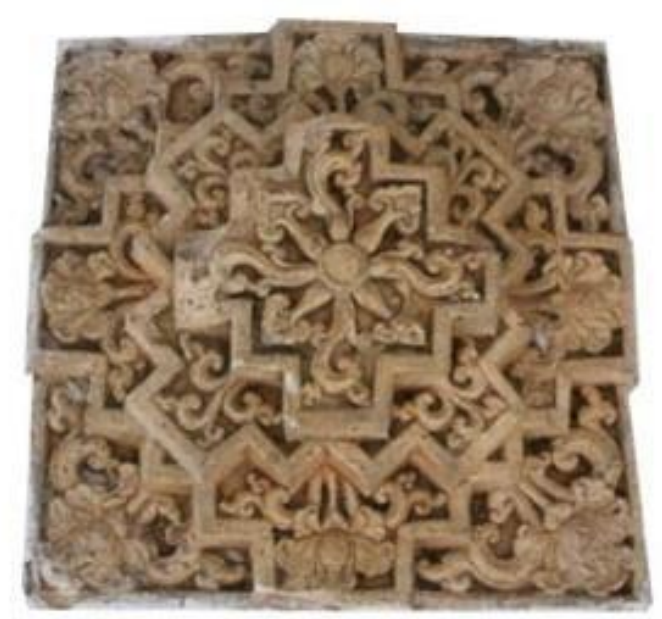

Gambar 5. Ukiran motif punden berundak bersusun geometris dengan bentuk bidang balok. Sumber: Na'am (2006, p. 109).

Panil dengan bentuk bidang balok berikutnya memiliki motif kala yang diukir di atasnya. Kala atau sengkolo dalam bahasa lain artinya adalah raksasa. Tidak secara utuh diukir dari kepala hingga kaki, umumnya motif kala hanya diukir bentuk kepala, dengan fokus utama adalah area wajah atau muka. Tentunya, berkesinambungan dengan motif makhluk hidup lainnya, ukiran dengan motif kepala kala ini tidak diukir dengan realistis, namun tetap digayakan dengan samar (stilasi) melalui bentuk motif sulur-suluran atau lunglungan khas Jepara yang meliuk-liuk indah dan simetris.

Umumnya motif kala diukir atau diimplementasikan dalam bangunan suci seperti pura atau candi dengan cara penggambaran realis. Motif kala dipercaya atau dimaknai mampu sebagai media simbol penolak bala atau marabahaya. Namun, motif kala yang digambar dengan stilasi pada ornamen dinding masjid Mantingan ini memiliki makna simbolik sebagai pesan terhadap pengunjung masjid yang akan melaksanakan ibadah untuk lebih mensucikan diri serta menghilangkan segala macam pikiran buruk dan perbuatan tercela. Harapannya, dengan sucinya hati, perbuatan dan pikiran kelak akan membuat pengunjung masjid menjadi lebih khusyu dalam menunaikan ibadahnya.

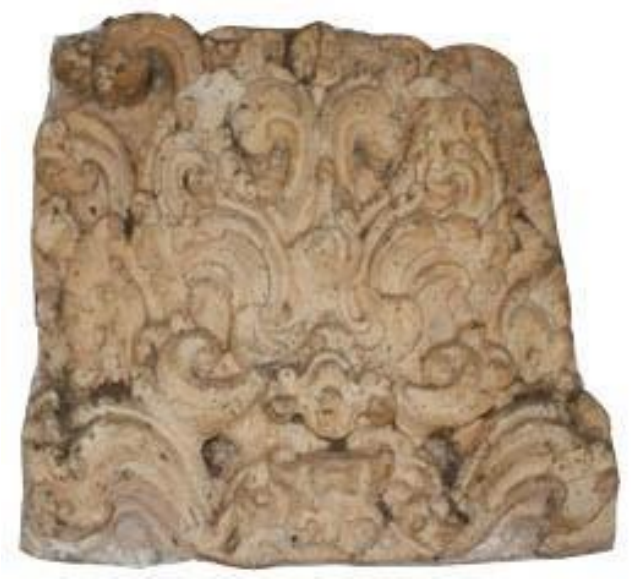

Gambar 6. Ukiran motif sengkala dengan bentuk bidang balok.

Sumber: Na'am (2006, p. 127). 
Panil ukiran dengan bentuk bidang bingkai atau frame menyerupai kurung kurawal, dapat diidentifikasi di dalamnya terukir rangkaian beberapa motif keragaman floral atau tumbuhan berupa pohon kelapa, pohon bambu, pohon pandan, bunga teratai, motif sekumpulan awan, motif hewan singa yang terstilasi, beberapa motif meru atau gunung yang keseluruhannya membentuk satu kesatuan pemandangan alam atau landscape. Pada panil landscape ini seniman seolah-olah ingin menggambarkan bahwasannya singa yang dikelilingi dengan aneka ragam floral yang tumbuh lebat dan pegunungan ini merupakan nafsu amarah dalam diri manusia harusnya dikurung erat dengan hal-hal yang lebih bermanfaat.

Sedangkan pada panil berikutnya kita dapat mengidentifikasi ukiran dengan sejumlah motif floral seperti kamboja, pandan dan beberapa sulur-suluran, kemudian motif candi Bentar, motif awan, motif sebuah bangunan serupa pendopo yang berkuncup serta motif gunung yang diukir 5 buah yang beberapa memiliki perbedaan tinggi dan besarnya. Candi Bentar dalam masyarakat setempat dikenal sebagai sebutan untuk pintu gerbang yang berupa gapura yang seolah-olah terbelah sempurna. Ia biasa ditemui ketika akan memasuki suatu tempat penting seperti pendopo, candi, masjid dan lain sebagainya. Pada panil dengan motif landscape kedua ini, seolah-olah seniman hendak menggambarkan pemandangan suatu tempat di mana terdapat pendopo dengan atapnya yang kuncup, masih asri dengan aneka tanaman disekitarnya, serta dikelilingi oleh 5 gunung yang mengitarinya.
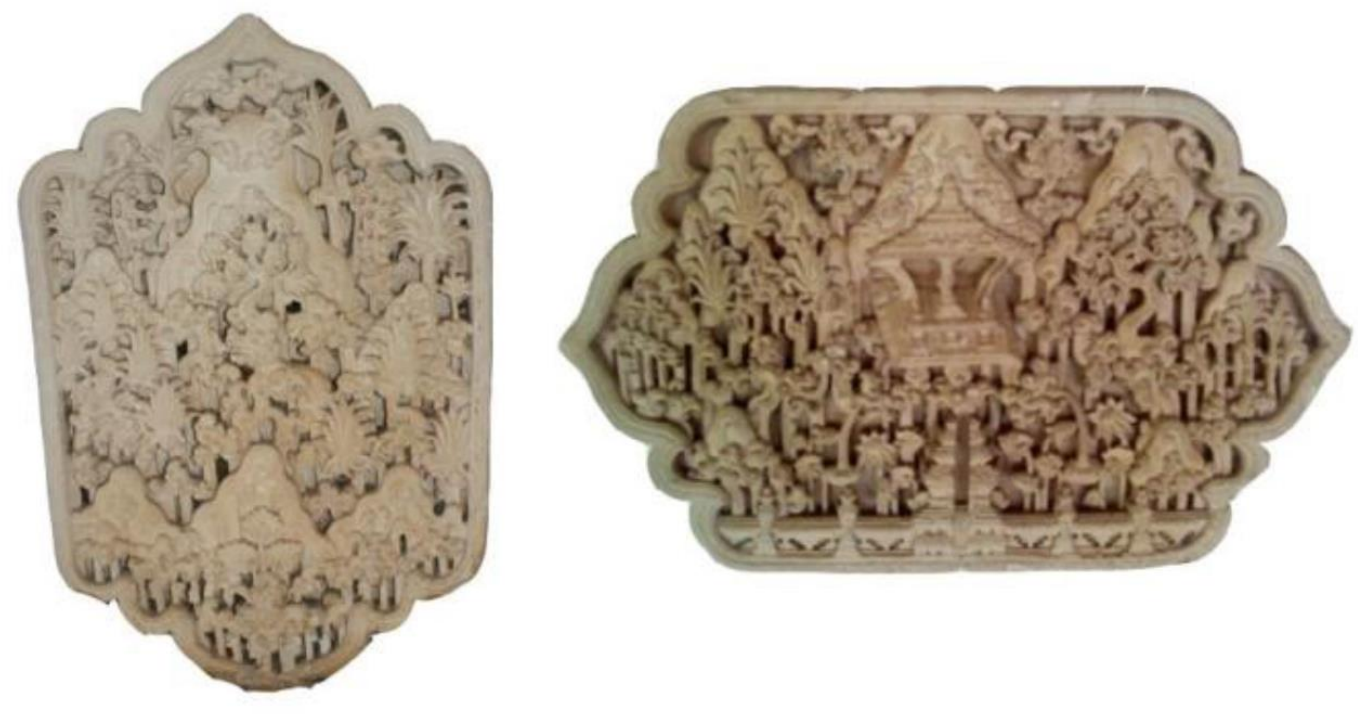

Gambar 7. Ukiran motif landscape dengan bentuk bidang frame kurung kurawal. Sumber: Na'am (2006, p. 89-90).

Motif terakhir adalah motif abstrak-simetris dengan bentuk bidang letter "W". motif ini memiliki ukiran abstrak lung-lungan sederhana yang melingkar dan meliuk-liuk. Warga setempat biasa menyebutnya sebagai ornamen garuda (sebagian yang lain menyebutnya kelelawar), karena bentuk bidangnya yang menyerupai garuda yang tengah mengepakkan sayapnya. Ornamen-ornamen dengan bentuk bidang seperti ini banyak ditemukan pada bagian depan atau serambi masjid, serta pada bagian dalam dan atas mihrab masjid Mantingan. Na'am (2006, p. 136) menyatakan bahwa ornamen dengan bentuk bidang letter "W" atau menyerupai burung garuda yang mengepakkan sayapnya ini memiliki makna kestabilan, kekokohan dan simetris. 

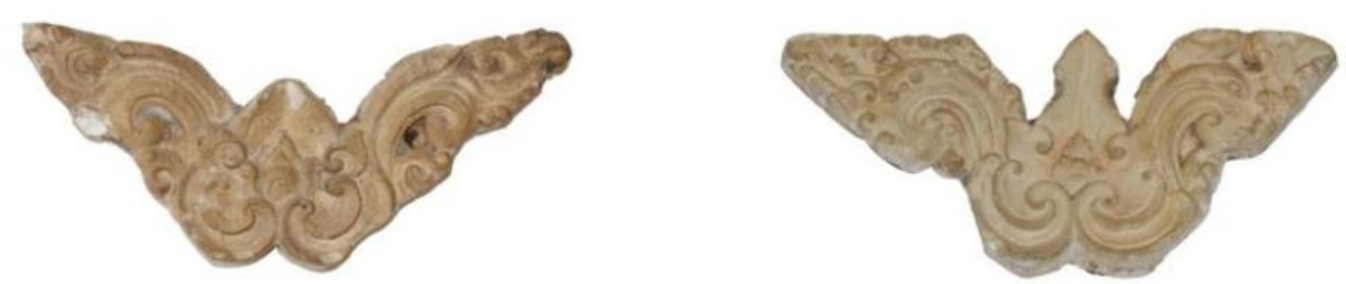

Gambar 8. Ukiran motif abstrak simetris dengan bentuk bidang letter "W". Sumber: Na'am (2006, p. 90).

\section{KESIMPULAN}

Nilai-nilai estetis terrepresentasi dalam sebuah media ukir yang kemudian dirancang hingga diukir penuh akan ornamen ukir yang indah, rumit, ngremit dan ngrawit sebagai indikator maju dan tingginya keahlian dan keterampilan seniman ukir Jepara pada masa tersebut. Pada masa dibangunnya masjid Mantingan, agama Islam tengah gencar-gencarnya dipelajari oleh keraton maupun masyarakat, hal ini menjadikan seniman ukir Jepara juga merasa ditantang untuk lebih mengasah kembali kreatifitasnya dalam mengukir ornamen dengan motif makhluk hidup seperti hewan, karena dalam salah satu ajaran Islam melarang adanya penggambaran makhluk bernyawa. Sehingga muncul solusi untuk penggayaan stilasi (samar) dalam mengukir motif beberapa hewan dengan tanpa mengurangi keindahan dalam mengukirnya.

Nilai-nilai simbolis yang terdapat pada setiap ornamen ukiran pada dinding masjid Mantingan merupakan bentuk falsafah hidup yang berguna bagi kehidupan masyarakat sekitar yang mengetahuinya. Nilai-nilai simbolis yang penuh falsafah kehidupan ini mampu terrepresentasikan dengan baik akibat dari bentuk komunikasi antar pemimpin (ratu) Jepara pada masa tersebut kepada warganya. Selain itu, nilai estetis dan simbolis yang diberikan pada setiap motif ornamen ukir ini juga mengindikasikan bahwa sang seniman ataupun kreatornya yakni Ratu Kalinyamat pada masa itu, ingin ikut serta dalam menyampaikan pesan dakwah Islam dengan cara menarik perhatian masyarakat Mantingan khususnya maupun Jepara secara umum yang belum masuk Islam sehingga mereka tertarik dan senang mengunjungi masjid.

\section{DAFTAR PUSTAKA}

Gustami, SP. (2000). Seni Kerajinan Mebel Ukir Jepara: Kajian Estetik Melalui Pendekatan Multidisiplin. Yogyakarta: Kanisius.

Irsyada, Abdulloh Eizzi. (2018). Kajian Perubahan Desain Ukiran Jepara pada Periode Abad XVI-XVIII dan Abad XIX, Ditinjau dari Faktor Penyama dan Faktor Pembedanya (Magister Thesis, Universitas Komputer Indonesia).

Mulyani, R. A. (2013). Respon Terhadap Ornamen Masjid Mantingan Jepara dalam Seni Lukis. Arty: Journal of Visual Arts, 2(1). 
Na'am, M. Fakhrihun. (2016). Pertemuan Antara Hindu, Cina dan Islam pada Ornamen Masjid dan Makam Mantingan, Jepara (Doctoral Dissertation, Institut Seni Indonesia Yogyakarta).

Rohidi, Tjetjep Rohendi. (2011). Metode Penelitian Seni. Semarang: Cipta Prima Nusantara Semarang.

Rohmat, N. (2009). Nilai Estetis dan Makna Simbolis Lampion Arak-arakan Takbir Mursal. Imajinasi, 5(2).

Sugiyono. (2012). Metode Penelitian Kuantitatif Kualitatif Dan R\&D. Bandung: CV. Alfabeta.

Sunarman, Y. B. (2010). Bentuk Rupa dan Makna Simbolis Ragam Hias di Pura Mangkunegaran Surakarta (Doctoral Dissertation, Universitas Sebelas Maret). 